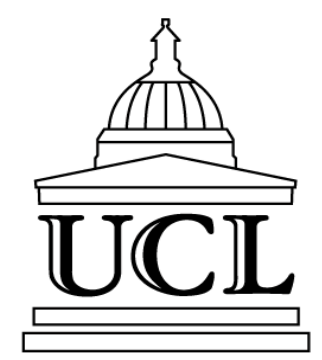

CENTRE FOR THE STUDY

OF ECONOMIC \& SOCIAL

CHANGE IN EUROPE

SCHOOL OF SLAVONIC \& EAST

EUROPEAN STUDIES

“Ownership Concentration, 'Private Benefits of Control' and Debt Financing"

Igor Filatotchev and Tomasz Mickiewicz

Working Paper No. 4

University College London

Centre for the Study of Economic and Social Change in Europe

Senate House, Malet Street, London, WC1E 7HU

Tel: 44(020) 78638517

Fax :44(020) 78628641

Email: csesce@ssees.ac.uk 


\title{
Ownership Concentration, 'Private Benefits of Control' and Debt Financing ${ }^{\mathbb{*}}$
}

\author{
Igor Filatotchev \\ School of Management and Organisational Psychology, Birkbeck College \\ e-mail: i.filatotchev@bbk.ac.uk \\ and \\ Tomasz Mickiewicz \\ SSEES, University College London \\ e-mail:t.mickiewicz@ssees.ac.uk
}

\begin{abstract}
Building on the 'law and economics' literature, this paper analyses corporate governance implications of debt financing in an environment where a dominant owner is able to extract ex ante 'private benefits of control'. Ownership concentration may result in lower efficiency, measured as a ratio of a firm's debt to investment, and this effect depends on the identity of the largest shareholder. Moreover, entrenched dominant shareholder(s) may be colluding with fixed-claim holders in extracting 'control premium'. One of possible outcomes is a 'crowding out' of entrepreneurial firms from the debt market, and this is supported by evidence from the transition economies.
\end{abstract}

JEL Classification: G21, G28, G32, G34

Keywords: ownership, benefits of control, debt

December 2001

ISSN 1476-1734

\footnotetext{
- This research forms part of the ACE-Phare project P98-1048-R "Corporate governance, relational investors, strategic restructuring and performance in Hungary and Poland". Corresponding author: Tomasz Mickiewicz, SSEES, UCL, Senate House, Malet St., London WC1E 7HU, U.K., Phone: 00-44-20-7862 8606; Fax: 00-44-20-7862 8642; E-Mail:t.mickiewicz@ ssees.ac.ul
} 


\section{Ownership Concentration, 'Private Benefits of Control' and Debt}

\section{Financing}

\section{Introduction}

There is a substantial body of research in financial economics and strategic management literatures that links the pattern and amount of stock ownership with managerial behavior, and, eventually, with corporate performance (Gibbs, 1993; Hoskisson et al., 1994; Jensen and Warner, 1988). However, most of the previous research is focused on large, publicly traded corporations with diffused ownership within the framework of the conventional US/UK model of corporate control, and little is known about the corporate governance implications of concentrated ownership (Holderness and Sheehan, 1988; Short, 1994). A fast growing literature on the optimal ownership structures of firms depending on the levels of 'private benefits of control' (e.g., Bennedsen and Wolfenzon, 2000; Grossman and Hart, 1988; Harris and Raviv, 1988) has extended governance research beyond the conventional US/UK environment and has recently become a focal point of theoretical and policy debates (Bebchuk, 1994; Filatotchev et al., 2001; La Porta et al., 1998; 2000b; Modigliani and Perotti, 1997).

This research is particularly important for countries with relatively low protection of minority investors and where expropriation of minority shareholders by the controlling shareholders is extensive. This expropriation may take various forms, such as misappropriation of investment resources, related-party transactions, use of transfer pricing, assets stripping and other forms of 'tunneling' of assets and revenue from firms (see La Porta et al, 1998, for an extensive discussion). As a result, the primary agency problem in such environment is not the failure of professional managers to satisfy the objectives of diffused shareholders, but rather the expropriation of minority shareholders by the large-block 
shareholders (La Porta et al., 2000a; Shleifer and Vishny, 1997). This opportunistic behavior would deter outside investment and negatively affect the firm's value (Jensen and Meckling, 1976; La Porta et al., 1998; Wruck, 1989). However, despite the agency costs associated with large-block share ownership, concentrated shareholders may resist the dilution of their equity stakes even in the long-run. Modigliani and Perotti (1997) suggest that, in an environment of poor legal enforcement, the value of control rights is generally greater than that which controlling shareholders could hope to gain by selling out shares to equity investors. Bebchuck $(1994 ; 1999)$ develops a rent-protection theory of corporate ownership structure, suggesting that when private benefits of control are large, concentrated ownership is the only viable arrangement. In his model, controlling shareholders will tend to maintain a lock on control since surrendering control would attract attempts to assemble a controlling stake by rivals seeking to capture these private benefits.

These arguments provide a number of important theoretical and practical implications. First, a relatively high ownership concentration in many developed and developing economies may be an equilibrium response to a low level of protection of minority shareholders. Building on the agency framework developed by Jensen and Meckling (1976) a number of authors suggest that a higher equity ownership by controlling shareholders enhances their interest in non-distortionary distribution of dividends (Filatotchev et al., 2001; La Porta et al., 2000a). When expropriation of private benefits of control involves costs, an increase in the size of the equity stake of a large-block shareholder would reduce the marginal benefits of expropriation (see Bennedsen and Wolfenzon, 2000; Claessens et al., 1999, for a discussion).

Second, an inadequate legislative and enforcement framework may hamper the development of equity markets and may account for the relative weight of intermediated credit as compared with direct equity financing (LaPorta et al., 1997; Modigliani and Perotti, 1997; Schleifer and Vishny, 1997). Moreover, fixed-claim holders may provide an effective 
counterbalance to opportunistic behavior of concentrated owners of cash-flow rights (Hart,

1995; Jensen, 1986). Debt can provide a hard mechanism in the sense of the need to meet interest payments and the bankruptcy procedures which can be invoked when there is a failure to meet such payments. It can also be associated with the provision of active monitoring through bank-corporate relationships involving regular information provision, face-to-face meetings, flexible interpretation of covenant breaches, etc. (Holland, 1994; Myers and Majluf, 1984). Finally, Dewatripont and Tirole (1994) argue that there is a complementarity between debt and equity in terms of effective corporate governance.

However, despite these considerable research advances, the theory of optimal ownership structure depending on the levels of 'private benefits of control' still has a number of conceptual and empirical gaps that require further analysis. First, the main bulk of studies within the 'law and economics' framework are focused on equity financing. Second, previous studies are mainly concerned with ex post expropriation of minority shareholders by largeblock shareowners, i.e., an expropriation before pro rata distribution of profits on investment. However, opportunistic dominant owners may attempt at ex ante misappropriation of investment resources before selecting an investment project. Finally, previous research on governance roles of debt says very little about the governance implications of a possible collusion between fixed-claim holders and dominant shareholders, and, indeed, there is very little research on organizational outcomes when the same party represents a combination of both!

In this paper we aim to close some of these gaps and develop a conceptual framework that analyses the effects of possible collusion between concentrated shareholders and fixedclaim holders, in environment where minority interests are not effectively protected. The

\footnotetext{
${ }^{1}$ So far, an ex ante misappropriation of investment funds and a possible collusion between fixed claim holders and controlling shareholders have been analysed in the context of 'looting' (Akerlof and Romer 1993; Cull et al. 2001). This framework describes an expropriation of ultimate providers of funds such as bank depositors, the government, etc., which eventually leads to a firm's bankruptcy.
} 
paper is organized as follows. In the next section we provide a review of literature that addresses the effects of 'private benefits of control' on a firm's investment decisions and performance. In the second section we discuss issues related to concentrated ownership and debt finance within the framework of a simple theoretical model. In the following section we analyze implications of a possible collusion between fixed-claim holders and concentrated owners of cash-flow rights in terms of 'crowding out' of entrepreneurial firms from the market of debt financing, and provide evidence from economies in transition. Conclusions are presented in the final section.

\section{Theoretical framework and literature review}

Previous research has recognized several possible governance roles for large-block shareholders, some of which are likely to be value-enhancing while others are likely to have negative effects (see Filatotchev et al., 2001; Shleifer and Vishny, 1997, for an extensive discussion).

Both strategy and agency perspectives traditionally focus on analysis of the possible incentive effects associated with concentrated share ownership. Jensen and Meckling (1976), for example, explain how the increase in entrepreneur/manager's cash flow rights constrains the consumption of perquisites and thus produces a positive effect on corporate valuation. Further research suggests that large-block outside ownership may also be an effective counter-balance to managerial opportunism. Companies may have large, undiversified shareholders that play a critical leadership and monitoring role. They have both the incentives and the means to restrain the self-serving behavior of managers (Maug, 1998; McConnel and Servaes, 1990; Zeckhauser and Pound, 1990). In addition, they make value-enhancing implicit contracts with employees and other stakeholders (Shleifer and Summers, 1988). From a strategic management perspective, large-block shareholders may not allow a poor strategy, such as diversification, to evolve into poor performance, therefore decreasing the magnitude of 
restructuring (Gibbs, 1993; Hoskisson et al., 1994).

Some researchers, however, have indicated that concentrated shareholding may create entrenchment effects in addition to incentives effects (McConnell and Servaes, 1990; Mikkelson and Partch, 1989; Morck et al., 1988), and, instead of imposing an efficient monitoring and control on managerial discretion, the large-block shareholders may produce their own set of agency costs (Roe, 1990). In particular, lack of diversification means that large shareholders are affected adversely by the company's idiosyncratic risk (Maug, 1998). This risk decreases their subjective value of investment and they may use an opportunity to collude with managers or shift wealth from minority shareholders to themselves. Gibbs (1993) argues that unaffiliated blockholders are generally passive and are likely to support managers in their quest for growth, instead of residual value. Pound (1988) also suggests that blockholders are likely to side with management (the strategic-alignment hypothesis), or that they can be influenced by existing business relationships with management (the conflict-ofinterest hypothesis).

Building on this research, some authors point out that ownership concentration per se may negatively affect the value of the firm when majority shareholders have a possibility to abuse their position of dominant control at the expense of minority shareholders (Bebchuk, 1994; Stiglitz, 1985), especially when legal protection of minority shareholders is weak. This abuse may be facilitated by specific legal arrangements, like differential voting rights (Grossman and Hart, 1988; Harris and Raviv, 1988), and may take various forms, ranging from cash flow appropriation and asset stripping through the use of cross-shareholdings and pyramids (La Porta et al., 1998). Concentration of cash flow rights may be accompanied by a more than proportional increase in voting rights, and this concentration of voting control may make expropriation less costly since it reduces the probability of minority shareholders effectively colluding against the controlling shareholder (Bebchuk, 1999). In addition, at some level of ownership concentration the distinction between insiders and outsiders 
becomes blurred. Blockholders, no matter what their identity is, may have strong incentives

to divert resources in ways that make them better off at the expense of other shareholders (Wruck, 1989).

However, the willingness of controlling shareholders to expropriate minority investors may be constrained by their financial incentives. Building on the agency framework developed by Jensen and Meckling (1996) a number of authors link these incentives with equity ownership by controlling shareholders that enhances their interest in non-distortionary distribution of dividends. Assuming that expropriation of private benefits of control involves costs, such as legal manoeuvring, setting up pyramids, etc., an increase in the size of the equity stake of a large-block shareholder would reduce the marginal net benefits of expropriation (see La Porta et al., 2000a, for a discussion). Other things equal, ownership concentration should lead to lower expropriation, since the incentive effect interferes with entrenchment. Therefore, large-block ownership may be recognized by minority shareholders as a signal of a better quality firm (Bennedsen and Wolfenzon, 2000), and these arguments are consistent with the assumption that, in established publicly traded firms, ownership concentration is a substitute for legal protections in providing the functions of corporate governance (La Porta et al., 1998). In other words, a firm's ownership structure may be an equilibrium response to an individual firm's operating characteristics and its competitive and legal environments (Demsetz and Lehn, 1985; Jensesn and Warner, 1988; Roe, 1990; Demsetz and Villalonga, 2001).

Building on this research, a number of studies suggest that cash flow ownership by the controlling shareholder mitigates the incentive for expropriation of minority shareholders, but does not eliminate it (Filatotchev et al., 2001; La Porta et al., 1999). As a consequence, equity markets are both larger in terms of the level of capitalization to the GNP and 'deeper' in terms of the development of market infrastructure in countries with good legal protection of minority shareholders (La Porta et al., 1997; 1999). Elsewhere, the firms have to rely more extensively on retained profits and bank loans as the main means of financing their investment projects 
(Modigliani and Perotti, 1997; Rajan and Zingales, 1995).

In case of the weak legal and regulatory framework and the large relative weight of intermediated credit to direct equity financing in many countries around the world, the relationship governance of either the Japanese or German models may substitute for open capital markets of the US/UK type. A number of authors raise the issue of the governance role of debt and debtholders (Hart, 1995; Jensen, 1986). Debt can provide a hard mechanism in the sense of the need to meet interest payments and the bankruptcy procedures which can be invoked when there is a failure to meet such payments. It can also be associated with the provision of active monitoring through bank-corporate relationships involving regular information provision, face-to-face meetings, flexible interpretation of covenant breaches, etc. (Both and Deli, 1999; Myers and Majluf, 1984). More generally, Dewatripont and Tirole (1994) show that there is a complementarity between debt and equity in terms of corporate governance functions.

These aspects of an integrated system of monitoring by banks in the West, may be more important in enforcing performance than a simple reliance on default. Banks and other relationship shareholders are generally found to develop intimate and well-informed relationships with company executives, which facilitates provision of funds for company expansion (Franks and Mayer 1997). This process is particularly suited to the contingency where the firm's activities are opaque to outsiders, either because of high technical complexity (e.g. evidenced by high levels of R\&D expenditure, see Zeckhauser and Pound, 1990; Roe, 1997), or when the firm is crucially dependent upon idiosyncratic personal relationships with clients or suppliers, thus hampering active monitoring by outside investors.

Another stream of research highlights the relevance of large diversified corporate groups in less developed economies. These groups may serve the function of creating a private capital market, where smaller firms have access to finance inside the group. 
Modigliani and Perotti (1997) suggest that the ability of a holding company or an 'in-house'

bank to capture the benefits from control ensures a steady supply of financing. These groups may also develop long-term relations with lenders to attenuate the risk of moral hazard. Empirical evidence indicates that Japanese firms associated with financial keiretstu are not as credit-constrained in their investment choices as independent firms (Berglöf and Perotti, 1994). Khanna and Palepu's (2000) 'institutional voids' theory suggests the development of diversified groups in emerging markets may be a response to market and legal imperfections that increase the transaction costs of external funding.

Thus, bank ownership and control of industrial firms can offer significant economies of scope that may be crucial to particular stages of national development. However, although they provide firms with ready access to funds for expansion, relationship investors have been criticized for personal involvement with executives in failing companies, where 'rescue packages' are the norm (Macey and Miller, 1997). In particular, Harris and Raviv (1990) provide evidence that German banks are reluctant to discipline managers in client companies, especially when they are linked to these companies through system of crossshareholding. Banks with board seats and/or shares in a firm have been seen to protect their investments by advocating massive internal cash transfers within German firms into hidden reserves, that can be used to smooth declining firm income in a crisis. This amounts to banks forming a coalition with managers to keep down dividends payable to outside shareholders (Baums, 1993). In addition, there is some evidence that bank holdings distort investment decisions: Thomas and Waring (1999) report that investment decisions in large, bankcontrolled firms in Japan and Germany are influenced more by liquidity considerations than by expected investment returns, as is the case in the US.

Therefore, there is an ambiguity concerning corporate governance effects of the fixed-claim holders as shareholders with dual (or multiple) roles within the firm. There may be either positive spillover effects or efficiency loss as shareholders perform other roles 
simultaneously (e.g., banks as shareholders, suppliers of credit and financial advisers),

enjoying information advantages as 'insiders' (Myers and Majluf, 1984). In the case of relationship investors, sophisticated financial institutions and legal provisions are needed to discourage the abuse of multiple roles. In terms of access to outside financing, banks and other fixed-claim holders with existing roles in the company must also be trusted (Barney and Hansen, 1994) as shareholders not to indulge in short-term opportunism, and/or collude with dominant shareholders raising their own economic rents in relation to their fixedpayment services, at the expense of the residual incomes of minority shareholders.

\section{The model}

A very simple model can illustrate the effect of poor protection of minority shareholder interests in case of debt financing. First, we consider an entrepreneurial firm that has valuable investment opportunities and little internal financial resources. The firm's investment expenditures $I$ are financed by a perpetuity $L=I^{2}$ which will pay an (exogenous) real interest $i$, where $0<i<1$. Both finance and investment relate to period zero. In all future periods, the firm will produce a net revenue $I^{\beta}-i L$, where $\beta$ is a productivity parameter, and $0<\beta<1$ because of diminishing returns to investment.

The entrepreneur maximises the net present value of his/her cash flow:

$$
\underset{L}{\operatorname{Max}} V=\int_{0}^{\infty}\left(L^{\beta}-i L\right) e^{-r t} d t=\frac{L^{\beta}}{r}-\frac{i L}{r}
$$

where $r$ is a subjective discount rate, $0<r<1$.

\footnotetext{
${ }^{2}$ We model finance this way for the sake of simplicity. It can be interpreted as an issue of a bond with a fixed yield and indefinite maturity (i.e. perpetuity). Another interpretation is that the finance for the investment project is raised through a new line of credit (say, where investment relates to working capital necessary to initiate new operations). However, the model can be easily expanded to
} 
The optimum amount of investment is determined by:

$$
I^{*}=L^{*}=\left(\frac{\beta}{i}\right)^{1 /(1-\beta)}
$$

It is clear that the level of investment (and borrowing) is negatively affected by the prevailing interest rate $(i)$, and positively affected by productivity $(\beta)$. This investment project generates positive net revenue that is appropriated by the owner-entrepreneur.

Now, let us consider a joint-stock company with a dominant shareholder who owns a percentage of voting shares, $\lambda$, where $0 \leq \lambda \leq 1$. In an environment of low protection of minority shareholders' rights, the dominant shareholder is able to extract the control premium $s$, and we define $s$ as the share of the fixed-claim finance $L$ that can be appropriated before investment $I$ $(0 \leq s \leq L)$. We do not specify the characteristics of these 'private benefits of control', as they may vary with the identity of the dominant owner. If corporate control remains with employees, we can assume that these benefits are consumed as wage income. Managers may maximize perks or use various 'tunnelling' schemes to re-direct part of external finance $(L)$ outside the company. The same relates to outside owners. What is important, all these actions will decrease the net present value of the firm. In this case, $I$ is no longer equal to $L$. Instead, $I=L-s$.

However, the expropriation of minority shareholders may be costly, since the controlling shareholder has to engage in legal but costly manoeuvring to divert finance, such as setting up intermediary companies, facing legal challenges, taking risks of being fined, etc. The debtproviders may introduce various restrictions on the use of a loan in the debt agreement, breaching debt covenants may involve penalties, and the minority shareholders may be compensated as a result of a court action. Therefore, the net private benefits of control are given by $s-c(s)$, where an expropriation cost function $c(s)$ has the following properties:

$$
c_{s}(s)>0, \quad c(0)=0
$$


If $c(s)=0$ for all $s$, we have a completely inefficient legal system. The opposite case is where the expropriation cost is high. If $c(s) \geq s$ for all $s$, the extraction of private benefits of control is no longer an attractive opportunity and we are back to the benchmark case of the entrepreneurial firm.

In a general case, the firm solves the following optimization problem:

$$
\operatorname{Max}_{L, s} \varphi=s-c(s)+\lambda V=s-c(s)+\lambda \int_{0}^{\infty}\left[(L-s)^{\beta}-i L\right] e^{-r t} d t=s-c(s)+\frac{\lambda(L-s)^{\beta}}{r}-\frac{\lambda i L}{r}
$$

s.t.c.: $i L-(L-s)^{\beta} \leq 0$

The Kuhn-Tucker conditions for maximum become:

$$
\begin{aligned}
& \frac{\lambda \beta(L-s)^{\beta-1}}{r}-\frac{\lambda i}{r}-\mu i+\mu \beta(L-s)^{\beta-1}=0 \\
& -\frac{\lambda \beta(L-s)^{\beta-1}}{r}+1-c_{s}(s)-\mu \beta(L-s)^{\beta-1}=0 \\
& \mu\left[i L-(L-s)^{\beta}\right]=0 \\
& i L-(L-s)^{\beta} \leq 0
\end{aligned}
$$

The positive expropriation costs create a trade-off between (net) private benefits of control and profits (shared with minority shareholders). As a result, it is likely that non-negative profit constraint is not binding $(\mu=0)$. For this case we obtain an equilibrium solution for $s$ :

$$
c_{s}\left(s^{*}\right)=1-\frac{\lambda i}{r}
$$

The left-hand side represents the marginal cost of present consumption of the private benefits of control. The right-hand side represents the marginal benefits of switching consumption from future periods to the present. This enables important comparative statics results. In particular, the extraction of private benefits of control decreases with ownership concentration, since:

$$
s_{\lambda}^{*}=-\frac{i}{r c_{s s}\left(s^{*}\right)}<0
$$


This is a counterpart of the Jensen and Meckling (1976) analysis of the incentive effect of concentrated entrepreneurial ownership on the consumption of perquisites (see Shleifer and Wolfenzon, 2000, for a detailed discussion). Similarly, the private benefits of control are lower when interest rate is high, as it makes expropriation relatively more expensive in terms of future financial costs:

$$
s_{i}^{*}=-\frac{\lambda}{r c_{s s}\left(s^{*}\right)}<0
$$

If the dominant shareholder is also a provider of finance, then one may expect a reduction in cost of finance $i$, but this reduction will be accompanied by an increase in expropriation of minority shareholders.

On the other hand, a higher (subjective) discount rate results in higher benefits of control:

$$
s_{r}^{*}=\frac{\lambda i}{r^{2} c_{s s}\left(s^{*}\right)}>0
$$

This result is also important, as the subjective discount rate may differ with the identity of owners. In particular, we may expect that this rate is higher for employee- and manager-owners as opposed to outside investors. An increase in opportunism associated with insider ownership is well documented in previous research with respect to equity finance (e.g., Blanchard and Aghion, 1996; Filatotchev et al., 1996; Frydman et al. 1996; Morck et al., 1988), and our model suggests that this may be a more general phenomenon.

Using the equation 4 we can obtain the optimal level of finance from the point of view of the dominant owner:

$$
L * *=\left(\frac{\beta}{i}\right)^{\frac{1}{1-\beta}}+s^{*}=I^{*}+s^{*}
$$

This equation clearly demonstrates that the firm will choose the same investment project $I^{*}$ as the entrepreneurial firm. However, it is in the interests of the dominant owner to increase the volume of finance beyond the investment needs in order to obtain private benefits of control at the 
expense of net profits, which s/he has otherwise to share with the minority shareholders. It means that a smaller proportion of debt funding is invested, as compared to the benchmark model, i.e.:

$$
L^{* *}>L^{*} \text { and, therefore, } \quad \frac{I^{* \beta}}{L^{* *}}<\frac{I^{* \beta}}{L^{*}}
$$

In other words, the economic return on debt financing in the firm with an opportunistic dominant owner is lower then in the entrepreneurial firm.

\section{Discussion and empirical evidence.}

Our model demonstrates that ownership concentration provides a possibility for a dominant owner to extract a 'control premium' at the expense of minority shareholders. However, unlike previous research that focused on equity financing, we suggest that this 'control premium' can be obtained even when the firm relies on intermediated forms of funding. Moreover, it appears that ownership concentration effects do not depend on the identity of the large-block shareholder. These findings are consistent with the proposition that at a high level of concentration the distinction between insiders and outsiders becomes blurred, and blockholders may have strong incentives to divert resources in ways that make them better off, at the expense of other shareholders (Wruck, 1989). Our research, however, suggests that the extent of the expropriation may be contingent on a decision-making horizon of the controlling shareholders, and the insiders' short-termism contributes to opportunistic behavior.

In addition, our analysis confirmes that ownership concentration may provide an incentive to the dominant owners to refrain from the ex ante expropriation of minority shareholders even when an investment project is funded by debt rather then equity. As equation (5) clearly shows, the private benefits of control are decreasing with an increase in ownership concentration, and this is consistent with the Jensen-Meckling incentive effect that has been identified in previous research (e.g., Claessens et al., 1999; Filatotchev et al., 2001; La Porta et al., 2000b). 
Our analysis develops further existing 'law and economic' research by suggesting

that debt financing may also create a set of agency costs which are ultimately borne by minority shareholders. More specifically, an ability of the dominant shareholder to extract ex ante private benefits is followed by a less efficient use of financial resources compared to an entrepreneurial firm as clearly indicated by the inequality (9). At the same time, a diversion of financial resources to a private use is accompanied by relative higher payments to the fixed-claim holders (i.e., $i L^{* *}>i L^{*}$ ), that represents a direct transfer of wealth from the minority shareholders and depresses the firm's value. As long as debt is regularly serviced, this expropriation is carried out with 'silent approval' by the fixed-claim holders who turn a blind eye to the opportunistic behavior of a dominant shareholder. In a Modigliani-Miller framework, the value of a share is the discounted value of the stream of its pro rata dividends; the method of financing and allocation of control being irrelevant. Our results demonstrate that the fixed-claim holders may collude with large-block shareholders who are able to extract a 'control premium' at expense of minority shareholders, with subsequent detrimental effects in terms of the firm's value. Building on the 'rent-protection' theory suggested by Bebchuk $(1994 ; 1999)$, it is possible to assume that concentrated ownership arises not because of its efficiency virtues but rather, despite its inefficiency disadvantages, because control is too valuable to entrenched concentrated owners. In such cases, concentrated owners would prefer to bear agency costs than give up their control.

Our analysis can contribute to the current debate concerning corporate governance roles of debt and the holders of fixed claims, in particular in a situation with 'lock-in' or 'bilateral monopoly' condition of 'sunk' investments (e.g., which cannot be easily extracted and re-deployed) or investments with extremely uncertain prospects (Berglöf, 1990; Klein et al., 1978). In this environment, high leverage is often considered as an effective control device capable of disciplining management, especially when combined with a strong affiliation to a lending institution. Thus, debt creates better monitoring opportunities, and the 
regular renewal of debts with fixed interest payments provides the lender with the essential details of the enterprise's activities as a continuous process. This can be further re-enforced with the help of auditing and business consulting roles of the fixed-claim holders (Jensen, 1986; Myers and Majluf, 1984). Developing a theory of capital structure based on 'incomplete contracting' Aghion and Bolton (1992) suggest that debt financing is a natural way of implementing contingent control allocations. In this framework, the ability for the entrepreneur of retaining control is contingent on meeting debt obligations. If the entrepreneur defaults s/he must transfer control rights to the fixed-claim holders, who may choose between reorganization or liquidation.

Our model shows that governance roles of debt may not be as straightforward as previous research suggests, in particular when dominant shareholders have enough power to extract ex ante benefits of control. Although ownership concentration creates substantial agency costs for minority shareholders, the opportunistic behavior of controlling owners is not restricted by debtholders, as long as the firm does not default on its debt servicing payments. This bodes well for most recent research that has questioned the ability and incentives of providers of intermediated finance, and banks in particular, to monitor and interfere with the firm-level strategic and operating decisions (Holland, 1994). For example, banks may collude with controlling parties concerning preferences for profit retention over distributing dividends (Baums, 1993). High retention reduce the risk that the company will default on its outstanding debt (this problem has been discussed with respect to German banks in Nunnenkamp, 1996).

A related issue is the analysis of governance roles of 'relationship investors' within large, diversified corporate groups. This analysis has become particularly important in the context of emerging market economies, where financial markets are characterized by a lack of adequate disclosure and weak corporate governance. In these economies, securities regulations are generally weak, and their enforcement is erratic. Within the framework of the 
'institutional void' theory, Khanna and Palepu (2000) suggest that relatively high transaction costs imply that the enterprise can often be better off as part of a large diversified business group. This group may effectively internalize ineffective markets, including capital markets, in particular when the group members are associated with a main bank through the web of cross-shareholding (La Porta et al., 1997; Macey and Miller, 1997; Modigliani and Perotti, 1997). In addition to the reduction of costs of finance, banks-shareholders may provide other services that may be vital to the firm, in particular when it is experiencing financial distress. For example, Berglöf (1990) especially emphasizes the role of commercial banks as reorganization specialists in those systems with pronounced alliance groups.

However, the role of banks as shareholders provides obvious incentives for banks to behave opportunistically as a result of their multiple roles and access to information: banks may handle the accounts of companies and thus be intimately aware of their cash-flow positions, while at the same time offering their services as investment brokers, management consultants and agents in corporate finance, seeking funds for the company abroad. While these multiple roles offer significant economies of scope, other shareholders may be disadvantaged, as bank-shareholders may have too much influence within the firm, and banks may be more concerned with their short-term credit positions than with long-term investment prospects (Coffee, 1991).

Our model provides a clear illustration to these arguments. Let us assume that the dominant shareholder is at the same time a provider of loan $L$ to the firm. Being a 'relationship investor', s/he may provide a loan at preferential interest rate $i$ ' $<$. From equation (8) it follows that this reduction in the costs of finance will be accompanied by an increase in investment $I^{*}$, in line with the 'institutional void' theory. However, as (6) clearly indicates, a reduction in $i$ will lead to an increase in private benefits of control $s *$. Moreover, being a dominant shareholder, the fixed-claim holder now has a direct incentive to expropriate minority shareholders by diverting part of $L$ to his/her private use! Without 
effective 'firewalls' between lending and investment departments, a bank with a

shareholding in a client firm may have less incentive to monitor the firm's investment decisions (Dittus and Prowse, 1996), and this would reduce the costs of expropriation $c(s)$. As a result, bank's share ownership may increase expropriation.

Our research may help to re-assess the consequences of the most recent trends in the transition economies associated with rapid development of holding companies. A particularly characteristic exemplification of this trend is the oil and gas industries in Russia, which are dominated by holding companies such as Gazprom, Sibneft, Tyumen Oil Company (TNK) and YUKOS. These companies are fixing the borders of their empires through intra-holding consolidations, mergers and single-share swaps. They are also characterised by concentrated ownership. Moreover, outside shareholders in each of them have suffered a dilution of their holdings, at different stages and to various degrees. In addition, many industries in Russia have also experienced a rapid development of FinancialIndustrial Groups (FIGs) that represent large diversified holding companies owned by banks, trading companies, etc. Very often FIGs and other holding companies are actively trying to fend off pressure for their members to restructure, and sometimes become simply a vehicle for creating pyramidal ownership structures. La Porta et al. (1999) suggest that these structures can be used by controlling shareholders to make existing shareholders pay the costs, but not share all the benefits, of new ventures. Therefore, instead of being the 'flagships' of fledging Russian private economy, these holding companies and FIGs may turn into examples of poor corporate governance and inefficiency.

A possible collusion between the dominant owners and providers of debt (or a passive acceptance by debt-holders the fact that the dominant owner is abusing its power at expense of minority shareholders) not only provides a negative impact on the firm's value, but can also create serious resource constraints for the development of entrepreneurial firms, in particular in emerging market economies without developed equity markets and large 
numbers of investors willing to fund Initial Public Offerings. Let us assume that both the

entrepreneurial firm and the joint-stock firm with a dominant owner have the same investment opportunity, $I^{*}$, but the credit available to them is limited to $2 L^{*}$. Even if we assume that the credit rating of both firms is the same, the relationship bank would consider lending to the joint-stock firm as a priority. However, this firm will borrow $L^{* *}>L^{*}$, since the dominant shareholder wants to extract the control premium from the loan. As a result, the entrepreneurial firm would end up with a lesser amount of finance that is not sufficient to fund its investment project. Effectively, it is 'crowded out' from the financial market by its counterpart. Our model directly links the extent of crowding out to the scale of the expropriation of minority shareholders in the environment where their interests are not protected by legal or reputational considerations.

The lack of funding is a particularly serious disadvantage for emergence and growth of de novo firms in emerging market economies, for which internal funds are limited and external finance is, therefore, essential. The results of a set of enterprise surveys conducted by the World Bank in Hungary, the Czech and Slovak republics, Poland and Russia investigating the obstacles faced by small and medium enterprises (SMEs) suggest that credit constraints constitute one of the main barriers to growth of SMEs (Pissarides, 1999). As Table 1 indicates, entrepreneurial sector accounts for a relatively small share in GDP in a vast majority of transition economies, and in the CIS in particular. This table also shows that entrepreneurial firms suffer from penalizing real rates of interest on loan finance compared to their larger counterparts. This may be explained by general inefficiencies of banking sector in transition economies, when banks may charge high interest partly because they consider the credit risks applying to SMEs higher that those applying to larger firms. From our research perspective, this may also be an outcome of 'credit rationing', when even entrepreneurial firms with good growth opportunities and adequate collateral are denied credits as opposed to their larger, usually privatized, counterparts with whom banks have 
long-standing relationships.

$\{$ Table 1$\}$

In our model, the extent of the crowding out effect directly depends on the costs of expropriation of minority shareholders, the later being determined by legal and competitive environment in a particular country (Filatotchev et al., 2001; La Porta et al., 2000a). Therefore, the quality of the legal system may impact not only on the development of equity markets, as has been indicated in previous research on the effects of private benefits of control, it should also affect the development of the entrepreneurial firms. Figure 1 clearly supports this assumption by showing strong and significant correlation between the size of entrepreneurial sector in various transition economies and the 'Legal transition indicators (financial regulations)' developed by the EBRD. Countries with the least developed and most volatile legal environment, such as Belarus, Central Asian countries and Caucasian republics have relatively small entrepreneurial sectors compared to Poland and the Baltic states. Russia and Ukraine are somewhere in between. Although the governments of these two countries have introduced a comprehensive set of laws regulating firms and financial markets, there are widespread problems with law enforcement, and this fact is reflected in the EBRD indicators (EBRD, 1999).

\section{$\{$ Figure 1\}}

Obviously, there may be other factors affecting the development of the entrepreneurial sector in a transition economy. In particular, Johnson et al. (1997) argue that new entrepreneurs face a choice between operating in official or unofficial sectors, and inadequate legal protection creates incentives to move into the 'shadow economy'. Without denying these arguments, we suggest that there also may be an important indirect role of governance factors, since distorted legal environment creates incentives for banks to collude with dominant owners in the large-size firms and to over-extend finance to this sector at expense of entrepreneurial firms. 
Our analysis leads to one obvious policy recommendation, i.e., to improve the legal environment in countries with low protection of minority shareholders so as to make their expropriation more difficult (La Porta et al., 1999). For example, OECD Principles of Corporate Governance (OECD, 1999) emphasize improved disclosure and transparency as key elements of corporate governance development strategy. In particular, it is suggested that the firms must disclose information about the ownership structure and mechanisms that allow some shareholders to gain control disproportionately to their legal ownership claims. The Principles also suggest a mandatory requirement of one-share one-vote. Moreover, in an environment of weak non-legal constraints on the power of controlling shareholders, company law should respond with strong rules that are designed to protect minority shareholders. These rules may include special procedures for approval of transactions in which large shareholders have a conflict of interest; requirements that a company issues and acquires its own shares only at market value; and redemption and appraisal rights for shareholders who do not approve of a company's strategic decisions (OECD, 1998). More importantly, as discussed by Hay et al. (1996), the protection of minority shareholders is determined not just by the legal rules but also by the quality of their enforcement.

However, La Porta et al. (1999) indicate that controlling shareholders generally do not support the legal reform that would enhance minority rights and they typically lobby against it. Protracted and slow reforms imply that the probability of abuses of minority shareholders in the future remain high. In many developing and emerging market economies, political links between enterprises, especially large holding companies, banks and all levels of the state are still very strong, and a deliberately inadequate legislative framework may also be a result of rent-seeking behavior of politicians who have strong formal and informal relations with powerful shareholders (Modigliani and Perotti, 1997). If the regulatory authorities in these countries are to follow the OECD guidelines, legal and regulatory reforms would need to be considerably more radical in nature, and address not only 
corporate governance problems but also such issues as the competition policy, taxation, accounting standards, etc. In addition to the equity markets, 'good corporate governance' rules should also include providers of debt, in particular when they are involved in a web of cross-shareownership with client firms.

Finally, because of the simplified nature of our model, this paper has not addressed several important issues that might be pursued in the future research.

First, we treat ownership concentration as exogenous and do not address the issue of what affects ownership concentration for a given firm. A number of authors have suggested that firm characteristics, such as size, industry, location, etc., may determine its ownership structure (Demsetz and Lehn, 1985; Jensesn and Warner, 1988; Demsetz and Villalonga, 2001). In other words, a firm's ownership structure is an equilibrium response to an individual firm's operating characteristics and its competitive environment, and parameter $\lambda$ may be endogenous. Still, an application of the exogenous case as in our simple model is justified by the characteristics of many emerging markets where conditions are transient, i.e. far from equilibrium and distribution of share ownership may be a result of 'non-equivalent' transfers of ownership titles through various privatisation schemes (Baltowski and Mickiewicz, 2000).

Second, equity ownership does not necessarily equate with control of the firm (see Short, 1994, for a comprehensive survey of relevant literature). Therefore, on both a theoretical and empirical level, it is very important to learn how concentrated shareholders may develop an ability to extract the control premium, and what channels of influence they normally use. In this regard, the evidence coming from emerging market economies is very sketchy and incomplete, and both investment community and regulatory authorities might benefit from research in this area. 


\section{Conclusions.}

Despite its limitations, this study provides important contributions to the literature and policy debates concerning corporate governance implications of various ownership patterns. It provides further support for the case of strong regulatory and capital market institutions and effective enforcement of the 'good corporate governance' rules, especially concerning the protection of minority shareholders. So far, most studies of corporate governance problems have focused on issues related to the consequences of opportunistic behavior of insiders and their opposition to outside control. Our research shows that the protection of minority shareholders from the blockholders' opportunism is as important for enterprise restructuring and development of an efficient system of corporate governance as protection against entrenched management. In addition, we extend this conclusion to an environment where debt finance is predominant and equity finance plays a minor role. We demonstrate that in such an environment, the collusion between dominant owners and financial institutions may lead to further efficiency distortions. 


\section{References}

Aghion, P. and P. Bolton, 1992, An incomplete contracts approach to financial contracting, Review of Economic Studies, 59, 473-494.

Akerlof, G. and P. Romer, 1993, Looting: The economic underworld of bankruptcy for profit, Brookings Papers on Economic Activity. Macroeconomics, 2, 1-73.

Baltowski, M and T. Mickiewicz, 2000, Privatisation in Poland: Ten years later, Post Communist Economies, 12, 425-443.

Barney, J and M. Hansen, 1994, Trustworthiness as a source of competitive advantage. Strategic Management Journal, 15 (Special Issue), 175-190.

Baums, T, 1993, Takeovers versus institutions in corporate governance in Germany, in: D.D. Prentice and P.R.J. Holland, eds., Contemporary Issues in Corporate Governance, (Clarendon Press, Oxford), 151-183.

Bebchuk, L, 1994, Efficient and inefficient sales of corporate control, Quarterly Journal of Economics, 109, 957-994.

Bebchuk, L, 1999, A rent-protection theory of corporate ownership and control, Working Paper, 7203, (National Bureau of Economic Research, Cambridge, MA).

Bennedsen, M and D. Wolfenzon, 2000, The balance of power in closely held corporations. Journal of Financial Economics, 58, 113-139.

Berglöf, E., 1990, Capital structure as a mechanism of control: A comparison of financial systems, in: M. Aoki, B. Gustafsson and O. Williamson, eds., The Firm as a Nexus of Treaties (MIT Press, Cambridge, MA).

Berglöf, E and E. Perotti, 1994, The governance structure of Japanese keiretsu, Journal of Financial Economics, 35, 45-57.

Blanchard, O. and P. Aghion, 1996, On insider privatisation, European Economic Review, 40, 759-766. 
Booth, J and D. Deli, 1999, On executives of financial institutions as outside directors, Journal of Corporate Finance, 5, 227-250.

Claessens, S, S. Djankov, J. Fan and L. Lang, 1999, Expropriation of minority shareholders: Evidence from East Asia, Policy Research Working Paper, 2088 (The World Bank, Washington D.C.)

Coffee, J., 1991, Liquidity versus control: The institutional investor as corporate monitor, Columbia Law Review, 91, 1277-1368.

Cull, R., J. Matesova, M. Shirley, 2001. Ownership Structure and the Temptation to Loot: Evidence from Privatised Firms in the Czech Republic, Mimeo (The World Bank, Washington D.C).

Demsetz, H. and K. Lehn, 1986, The structure of corporate ownership: Causes and consequences, Journal of Political Economy, 93, 1155-77.

Demsetz, H. and B. Villalonga, 2001, Ownership structure and corporate performance, Journal of Corporate Finance, 7, 209-233.

Dewatripont, M. and J. Tirole, 1994, A theory of debt and equity. Diversity of securities and management-shareholders congruence, Quarterly Journal of Economics, 109, 10271054.

Dittus, P. and S. Prowse, 1996, Corporate Control in Central Europe and Russia: Should Banks Own Shares?, in: R. Frydman, C. Gray, A. Rapaczynski, eds., Corporate Governance in Central Europe and Russia, Vol. 1 (CEU Press, Budapest) 20-67.

EBRD, 1999. Law in Transition (European Bank for Reconstruction and Development, London).

Filatotchev, I., R. Hoskisson, T. Buck and M. Wright, 1996, Corporate restructuring in Russian privatisations: Implications for US investors, California Management Review, 38, 87-105. 
Filatotchev, I., R. Kepelyushnikov, N. Dyomina, S. Aukusionek, 2001, The effects of ownership concentration on investment and performance in privatised firms in Russia, Managerial and Decision Economics, 22, 299-313.

Franks, J. and C. Mayer, 1997, Corporate ownership and control in the UK, Germany, and France, Journal of Applied Corporate Finance, 9, 30-45.

Frydman, R., K. Pistor, A. Rapaczynski, 1996, Exit and voice after mass privatisation: the case of Russia, European Economic Review, 40, 581-588.

Gibbs, P., 1993, Determinants of corporate restructuring: The relative importance of corporate governance, takeover threat and free cash flow, Strategic Management Journal, 14, 51-68.

Grossman, S. and O. Hart, 1988, One share-one vote and the market for corporate control, Journal of Financial Economics, 20, 175-202.

Harris, M and A. Raviv, 1990. Capital structure and the information role of debt, Journal of Finance, 45, 321-350.

Hart, O., 1995, Firms, Contracts and Financial Structure, (Oxford UP, Oxford).

Hay, J., A. Shleifer and R. Vishny, 1996. Toward a theory of legal reform, European Economic Review, 40, 559-567.

Holderness, C.G. and D.P. Sheehan, 1988, The role of majority shareholders in publicly held corporations, Journal of Financial Economics, 20, 317-346.

Holland, J., 1994, Bank lending relationships and the complex nature of bank-corporate relations, Journal of Business Finance and Accounting, 21, 367-393.

Hoskisson, R, R. Johnson and D. Moesel, 1994, Corporate divestiture intensity in restructuring firms: Effects of governance, strategy and performance, Academy of Management Journal, 3, 1207-1251.

Jensen, M., 1986, Agency costs of free cash flow, corporate finance, and takeovers. American Economic Review, 76, 323-329. 
Jensen, M and W. Meckling, 1976, Theory of the firm: Managerial behavior, agency costs, and ownership structure, Journal of Financial Economics, 3, 305-360.

Jensen, M. and J. Warner, 1988, The distribution of power among corporate managers, shareholders, and directors, Journal of Financial Economics, 20, 3-24.

Johnson, S., D. Kaufmann and A. Shleifer, 1997, Politics and Entrepreneurship in Transition Economies, Working Paper, 57 (William Davidson Institute, University of Michigan).

Khanna, T and K. Palepu, 2000, The future of business groups in emerging markets: Longrun evidence from Chile, Academy of Management Journal, 34, 268-285.

Klein, B., R. Crawford and A. Alchian, 1978, Vertical integration, appropriable rents and the competitive contracting process, Journal of Law and Economics, 21, 297-326.

La Porta, R., F. Lopez-de-Silanes, A. Shleifer and R. Vishny, 1997, Legal determinants of external finance, Journal of Finance, 52, 1131-1150.

La Porta, R., F. Lopez-de-Silanes, A. Shleifer and R. Vishny, 1998, Law and finance, Journal of Political Economy, 106, 1113-1155.

La Porta, R., F. Lopez-de-Silanes and A. Shleifer, 1999, Corporate ownership around the world, Journal of Finance, 54, 471-517.

La Porta, R., F. Lopez-de-Silanes, A. Shleifer, R. Vishny, 2000a, Investor Protection and Corporate Valuation, Mimeo (Harvard University).

La Porta, R, F. Lopez-de-Silanes, A. Shleifer and R. Vishny, 2000b, Investor protection and corporate governance, Journal of Financial Economics, 58, 3-27.

Macey, J. and G. Miller, 1997, Universal banks are not the answer to America's corporate governance 'problem': A look at Germany, Japan and the US, Journal of Applied Corporate Finance, 9, 57-73.

Maug, E., 1998, Large shareholders as monitors: Is there a trade-off between liquidity and control?, Journal of Finance, 53, 65-92. 
McConnell, J. and H. Servaes, 1990, Additional evidence on equity ownership and corporate value, Journal of Financial Economics, 27, 595-612.

Mikkelson, W.W. and M.M. Partch, 1989, Managers' voting rights and corporate control, Journal of Financial Economics, 25, 263-290.

Modigliani, F. and E. Perotti,1997, Protection of minority interest and the development of security markets, Managerial and Decision Economics, 18, 519-528.

Morck, R., A. Shleifer and R. Vishny, 1988, Management ownership and market valuation: An empirical analysis, Journal of Financial Economics, 20, 293-316.

Myers, S.C. and N.S. Majluf, 1984, Corporate financing and investment decisions when firms have information that investors do not have, Journal of Financial Economics, $20,187-221$.

Nunnenkampf, P., 1996, The German model of corporate governance. Basic features, critical issues, and applicability to transition economies, Working Paper, 713 (Kiel Institute of World Economics).

OECD,1999, OECD Principles of Corporate Governance (OECD, Paris).

Pissarides, F., 1999, Is the lack of funds the main obstacle to growth? EBRD's experience with small- and medium-sized businesses in Eastern and Central Europe, Journal of Business Venturing, 14, 519-539.

Pound, J., 1988, Proxy contests and the efficiency of shareholder oversight, Journal of Financial Economics, 20, 237-265.

Rajan, R. and L. Zingales, 1995. What do we know about capital structure? Some evidence from international data, Journal of Finance, 50, 1421-1460.

Roe, M., 1990, Political and legal restraints on ownership and control of public companies, Journal of Financial Economics, 27, 7-42.

Roe, M., 1997, The political roots of American corporate finance, Journal of Applied Corporate Finance, 9, 8-22. 
Shleifer, A. and R. Vishny, 1997, A survey of corporate governance, Journal of Finance, 53, 2, 737-784.

Shleifer, A. and D. Wolfenzon, 2000, Investor protection and equity markets, Mimeo (Harvard University).

Short, H., 1994, Ownership, control, financial structure and the performance of firms, Journal of Economic Surveys, 8, 203-249.

Stiglitz, J., 1985, Credit markets and the control of capital, Journal of Money, Credit and Banking, 17, 133-152.

Thomas, L.G. III and G. Waring, 1999, Competing capitalisms: Capital investments in American, German and Japanese Firms, Strategic Management Journal, 20, 3, 729-748.

Wruck, K., 1989, Equity ownership concentration and firm value. Evidence from private equity financing, Journal of Financial Economics, 23, 3-28.

Zeckhauser, R. and J. Pound, 1990, Are Large Shareholders Effective Monitors? An Investigation of Share Ownership and Corporate Governance, in: R. Hubbard, ed., Asymmetric Information, Corporate Finance and Investment (University of Chicago Press, Chicago) 149-180. 
Table 1. Legal Environment and the Development of Entrepreneurial Sector

\begin{tabular}{|c|c|c|c|}
\hline Country & $\begin{array}{l}\text { Size of entrepreneurial } \\
\text { sector, } 1997 \text { (\% of } \\
\text { GDP) }\end{array}$ & $\begin{array}{l}\text { Cost of loan financing, } \\
1996^{\mathrm{a}}\end{array}$ & $\begin{array}{l}\text { Legal transition } \\
\text { indicator: financial } \\
\text { regulations } 1998^{\mathrm{b}}\end{array}$ \\
\hline \multicolumn{4}{|c|}{ Central Eastern Europe and Baltic States } \\
\hline Albania & 50 & $\mathrm{n} / \mathrm{a}$ & $2-(1.7)$ \\
\hline Bulgaria & 40 & 27 & $3(3.0)$ \\
\hline Croatia & 45 & $\mathrm{n} / \mathrm{a}$ & $3(3.0)$ \\
\hline Czech Republic & 30 & 7.2 & $3(3.0)$ \\
\hline Estonia & 50 & -3 & $3(3.0)$ \\
\hline Hungary & 45 & 9.7 & $4(4.0)$ \\
\hline Latvia & 50 & 4 & $3(3.0)$ \\
\hline Lithuania & 40 & 9.3 & $3-(2.7)$ \\
\hline Macedonia & 40 & $\mathrm{n} / \mathrm{a}$ & $2(2.0)$ \\
\hline Poland & 50 & 3.1 & 4- $(3.7)$ \\
\hline Romania & 35 & 31.2 & $3-(2.7)$ \\
\hline Slovakia & 25 & 10.2 & $3-(2.7)$ \\
\hline Slovenia & 45 & 15.1 & $3(3.0)$ \\
\hline \multicolumn{4}{|c|}{ Commonwealth of Independent States } \\
\hline Armenia & 35 & $\mathrm{n} / \mathrm{a}$ & $2(2.0)$ \\
\hline Azerbaijan & 25 & $\mathrm{n} / \mathrm{a}$ & $2-(1.7)$ \\
\hline Belarus & 10 & 35 & $1(1.0)$ \\
\hline Georgia & 25 & $\mathrm{n} / \mathrm{a}$ & $1(1.0)$ \\
\hline Kazakhstan & 20 & $\mathrm{n} / \mathrm{a}$ & $2(2.0)$ \\
\hline Kyrgyzstan & 35 & $\mathrm{n} / \mathrm{a}$ & $2(2.0)$ \\
\hline Moldova & 20 & 34 & $2(2.0)$ \\
\hline Russia & 20 & 27 & $3-(2.7)$ \\
\hline Tajikistan & 15 & $\mathrm{n} / \mathrm{a}$ & $1(1.0)$ \\
\hline Turkmenistan & 15 & $\mathrm{n} / \mathrm{a}$ & $1(1.0)$ \\
\hline Ukraine & 30 & 25 & $2(2.0)$ \\
\hline Uzbekistan & 30 & $\mathrm{n} / \mathrm{a}$ & $2-(1.7)$ \\
\hline
\end{tabular}

Notes:

a) Cost of lending is calculated as the difference between market lending rate to SMEs and consumer price inflation.

b) Numbers in brackets represent our mapping of the EBRD indicators into numbers.

Sources:

(i) Th measure of financial regulation quality is taken from EBRD 1999, Table 2.2.2.

(ii) The size of the 'enterpreneurial sector' is taken from Johnson et al. (1997), Appendix 3.

(iii) Data on cost of loan financing is from Pissarides (1999). 
Figure 1. The quality of financial regulations and the size of enterpreneurial sector in GDP

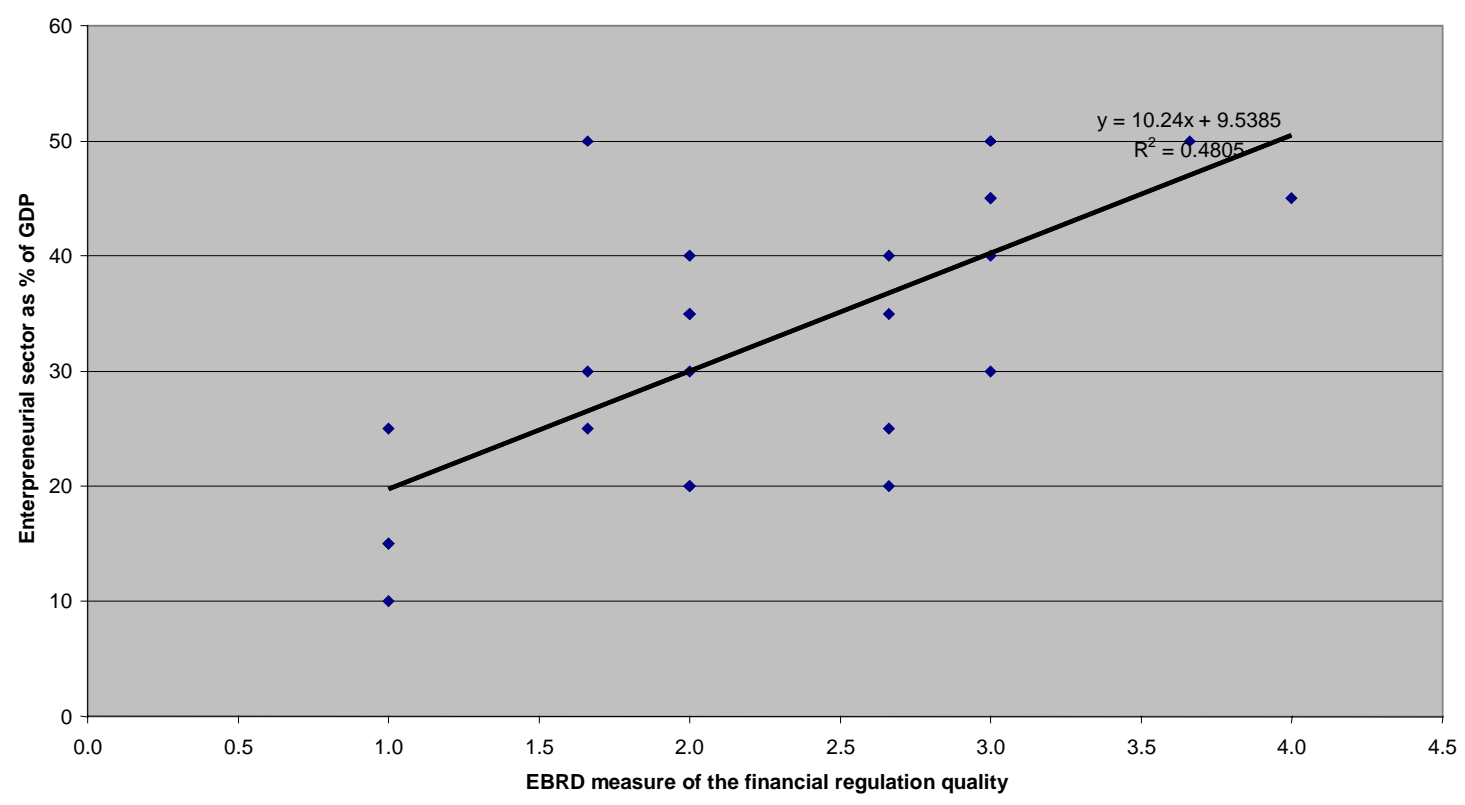




\section{WORKING PAPERS SERIES IN ECONOMICS AND BUSINESS}

Series Editor : Slavo Radosevic (email: s.radosevic@ssees.ac.uk)

- No. 8 February 2002

"Changes in Corporate Governance Structures in Polish Privatised Companies"

Piotr Kozarzewski

- No. 7 January 2002

"Patterns of Preservation, Restructuring and Survival: Science and Technology Policy in Russia in the Post Soviet Era"

Slavo Radosevic

- No. 6 January 2002

"Russia and the IMF: Pseudo Lending for Pseudo Reforms"

\section{Milan Nikolic}

- No. 5 January 2002

"Endogenous Ownership Structure: Factors Affecting the Post-Privatization Equity in Largest Hungarian Firms"

Kate Bishop, Igor Filatotchev and Tomasz Mickiewicz

- No. 4 December 2001

"Ownership Concentration, 'Private Benefits of Control' and Debt Financing”

Igor Filatotchev and Tomasz Mickiewicz

- No. 3 June 2001

"Videoton: the Growth of Enterprise through Entrepreneurship and Network Alignment"

\section{Slavo Radosevic and Deniz Eylem Yoruk}

- No. 2 June 2001

"The First Phase of the Internationalization Process: Export Determinants in Firms of the Former Soviet Union."

\section{K.Bishop}

- No. 1 April 2001

"The Issues of Enterprise Growth in Transition and Post-transition Period: the Case of Polish 'Elektrim'."

\section{S.Radosevic, D.Dornisch, D.E.Yoruk}

The papers can be accessed on the following web URL: www.ssees.ac.uk/economic.htm 